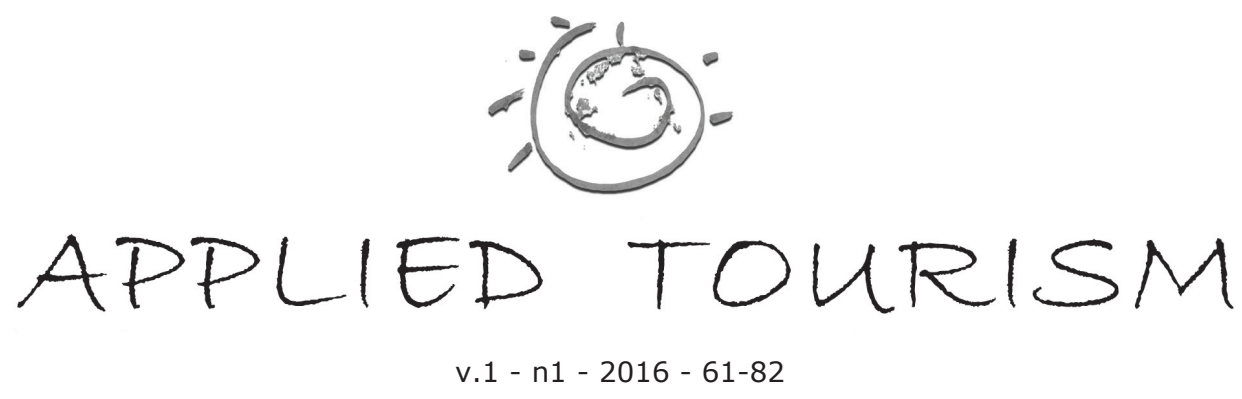

\title{
ANÁLISE DA METODOLOGIA DE COLETA DE DADOS ESTATÍSTICOS DE VISITAÇÃO NO PARQUE NACIONAL DO IGUAÇU - CASO PASSE COMUNIDADE
}

\section{ANALYSIS OF DATA COLLECTION METHODS ON THE VISITS TO THE IGUASSU NATIONAL PARK - CASE COMMUNITY PASS}

\author{
Ana Cristina R. de Olivera - Pós-Graduanda em Gerenciamento de Projetos - Fundação \\ Getúlio Vargas - FGV. E-mail: anah_turismo@hotmail.com \\ Claudio Alexandre de Souza - Doutor em Geografia - Universidade Federal do Paraná UFPR. \\ E-mail: cas_tur@yahoo.com.br
}

Recebido/Received: 10 setembro/september 2014. Aprovação/Approval: 18 janeiro/january 2015.

\begin{abstract}
Resumo: O artigo teve como objetivo analisar a metodologia utilizada para coletar dados estatísticos de visitação da comunidade em um atrativo natural, o estudo foi desenvolvido através de cinco etapas, que consistiram em revisão teórica e documental, obtenção da autorização necessária para a coleta de dados, elaboração do instrumento de coleta de dados, seleção da amostra, e a análise dos dados. O procedimento realizado no Parque Nacional do Iguaçu foi selecionado como amostra, posteriormente o mesmo foi analisado de acordo com a revisão bibliográfica acerca da importância da realização de pesquisas, e as metodologias e variáveis aplicadas ao turismo, que foram comparadas ao método utilizado no atrativo, concluindo que parte das metodologias e variáveis utilizadas em turismo pode ser aplicável aos atrativos turísticos.
\end{abstract}

\begin{abstract}
This article aims at analyzing the statistical methods for tourism. In particular, it looks into the methodology applied for data collection on the visits of the Parque Nacional do Iguaçu, a natural attraction. The research was developed in five stages: literature review, the attainment of permission for data collection, preparation of data collection instruments, sample selection and data analysis. The procedure performed in the Parque Nacional do Iguaçu was selected as a sample. It was subsequently analyzed according to the literature review on the importance of conducting research, and the methods and variables applied to tourism, which were compared to the method used in that natural tourist attraction. The conclusion is that some of the methods and variables used in tourism research can be applied to tourist attractions.
\end{abstract}


Palavras-chave: Metodologia; Estatística; Atrativo Natural; Comunidade.

\section{INTRODUÇÃO}

Os estudos estatísticos são percebidos como instrumentos importantes na mensuração do fenômeno e avaliação do seu impacto, o que possibilita a elaboração de diagnósticos que auxiliam a gestão do setor, além de serem potencialmente utilizados para estudar o comportamento da atividade turística, permitindo que se observem, e que se realizem previsões acerca da atividade turística (Salgado \& Cravo, 2005).

Para isso o objetivo deste estudo visa analisar a metodologia estatística para cálculo de demanda, utilizada para coletar dados estatísticos de visitação de um atrativo turístico natural - Parque Nacional do Iguaçu (PNI), mais especificamente a metodologia de coleta de dados de visitantes do Passe Comunidade.

O Passe Comunidade é um benefício para moradores das cidades limítrofes ao PNI, para obtê-lo é necessário comprovar residência com alguns dos documentos estabelecidos pelo Instituto Chico Mendes de Conservação da Biodiversidade (ICMBio) em regulamentos e portarias.

Através da análise foi possível verificar que algumas das metodologias e variáveis, identificadas como as principais no fornecimento de informações sobre a atividade turística, são aplicáveis também para um atrativo turístico natural, como é o caso do PNI aqui analisado.

A metodologia estatística para cálculo da demanda é uma tecnologia simples que inova, no entanto é uma técnica que já deveria estar difundida, simplificando a gestão, tornando-a mais eficiente, atribuindo maior competitividade aos atrativos turísticos do país.

Observou-se ainda que o PNI busca manter um relacionamento com a comunidade do entorno da unidade, observando que esta pode ser uma alternativa para sensibilizá-la e promover a conservação da área, e para isso contabiliza separadamente esta demanda por município.

O artigo está dividido em quatro partes: na primeira é apresentado o embasamento teórico, contendo o estudo dos temas correlatos ao objetivo do estudo, a segunda trata da metodologia utilizada para o estudo, na terceira parte são apresentados e analisados
Keywords: methods, statistics, natural attraction, community

\section{INTRODUCTION}

Statistics are an important tool for measuring and evaluating a phenomenon impact, putting forward data valuable for management purposes. In addition, statistics can be of great potential value to study touristic activity, describing and analyzing it as well as trend forecasting (Salgado \& Cravo, 2005).

Therefore, the objective of this study is to analyze the statistical methods for demand estimation, used to collect data on visits of the natural tourist attraction, National Park of Iguaçu (Parque Nacional do Iguaçu - PNI)1. More specifically the methodology used to collect data about visitants using a Community Pass.

The Community Pass is a benefit for the inhabitants of the cities bordering the PNI. It is necessary to attest residency to get it, filling in the required forms by Instituto Chico Mendes de Conservação da Biodiversidade - ICMBio (Institute Chico Mendes for the Biodiversity Conservation).

Through analysis, it was verified that some of the methods and variables identified as key in providing information on tourism activity, are also applicable to a natural tourist attraction, as is the case of PNI examined here.

The statistical method for demand estimation, however innovative, is a simple technique; it should be more widespread, thus simplifying management, making it more efficient and turning the country's tourist attractions more competitive.

It was also observed that the PNI seeks to maintain a relationship with the community around it, noting that this may be a way to raise awareness and promote the conservation of the area; therefore, the PNI considers the demand sorted by the municipality of origin of visitants.

The article is divided into four parts: first the theoretical background is presented, containing the study related to the purpose of the study subjects, the second discusses the methodology used for the study, the second discusses the methodology for the study, in the third part are presented and analyzed 
os dados obtidos a partir da pesquisa bibliográfica e documental, posteriormente apresentam-se as considerações finais onde é observado se o objetivo da pesquisa foi alcançado, e destacam-se as recomendações para próximas pesquisas acerca deste tema, e por fim as referências do texto.

\section{EMBASAMENTO TEÓRICO}

O embasamento teórico do estudo está organizado em cinco partes, onde na primeira é abordado o histórico e território do PNI, a segunda parte apresenta o Passe Comunidade, na terceira parte são comentadas as principais metodologias utilizadas em turismo, e na quarta e quinta partes são estudados os principais tipos de variáveis e variáveis em turismo respectivamente.

\section{HISTÓRICO E TERRITÓRIO DO PNI}

O conteúdo a seguir está organizado em duas partes, onde na primeira é comentado sobre o território do PNI, e no que consistiu a concessão de suas áreas, e posteriormente é apresentado o objetivo da unidade, e listadas as concessionárias existentes na UC.

O PNI é uma unidade de proteção integral, criada em 1939, segundo o Decreto No 1.035 (Brasil, 1939), e está situada no sul do Brasil, e região sudoeste do estado do Paraná. Em 1998 o PNI foi aberto para concessão pelo Instituto Brasileiro do Meio Ambiente e dos Recursos Naturais Renováveis (IBAMA), entidade que administrava o PNI.

$\mathrm{Na}$ época, a proposta consistia na liberação de áreas específicas para o aproveitamento econômico, sendo estas correspondentes a 3\% do território do Parque, que é de $185.262,5$ mil hectares (Cataratas do Iguaçu S/A, 2012).

Devido a sua beleza cênica o PNI foi a primeira Unidade de Conservação (UC) do Brasil a ser instituída como Sítio do Patrimônio Mundial Natural pela Organização das Nações Unidas para a Educação, a Ciência e a Cultura (UNESCO), no ano de 1986, atualmente é administrada pelo ICMBio, e abriga o maior remanescente de floresta Atlântica (estacional semidecídua) da região sul do Brasil (ICMBio, n.d.).

O PNI foi criado com o intuito de conservar a biodiversidade e seus ecossistemas conforme descrito na lei de $n^{\circ} 9.985$ (Brasil, 2000), sendo permitido o uso indireto de seus recursos naturais para atividades como, the data obtained from the bibliographic and documentary research, then presents the final considerations where it is observed that the objective was achieved, and stand out recommendations for future research on this subject, and finally the text references.

THEORETICAL FRAMEWORK

The theoretical framework of this study is organized into five sections: the first addresses the history of the territory of PNI; the second part presents the Community Pass; in the third part, the main methods used in tourism research are commented; and in the fourth and fifth parts the main types of variables and variables in tourism, respectively, are studied.

\section{HISTORY AND TERRITORY OF PNI}

The following content is divided in two parts: in the first part, the formation and the concession of areas of the PNI territory is examined and in the second part it is presented the objective of the PNI and the concessionaires installed inside the conservation unit are listed.

The PNI is a strict nature reserve, created in 1939, according to Act no 1.035 (BRASIL 1939), it is located in the south of Brazil and in the southwest of Paraná state. In 1998 PNI was opened to concessions by the Brazilian Institute of Environment and Renewable Natural Resources (Instituto Brasileiro do Meio Ambiente e dos Recursos Naturais Renováveis - IBAMA), a federal agency that used to manage PNI.

At the time, the proposal allowed economic exploitation in specific areas, corresponding to $3 \%$ of the territory of the PNI, which is 185,262.5 hectares (Cataratas do Iguaçu S/A, 2012).

Due to its scenic beauty, the PNI was the first Nature Conservation Unit to be nominated as World Natural Heritage by United Nations Educational, Scientific and Cultural Organization (UNESCO), in 1986. Currently it is managed by ICMBio, and contains the largest remaining Atlantic Forest area (semi-deciduous forest) in south of Brazil (ICMBio, n.d.).

The PNI was created to conserve biodiversity and its ecosystems as described in Act No. 9985 (Brasil, 2000). The indirect use of its natural resources is permitted for 
o desenvolvimento de pesquisas científicas, educação ambiental, recreação em contato com a natureza e turismo ecológico (Melo, Soares, Siqueira \& Kirschner, 2006).

Atualmente existem seis concessionárias que prestam serviços de infraestrutura turística: Macuco Safári, Macuco Ecoaventura, Cânion Iguaçu, Hotel das Cataratas, Helisul e Cataratas do Iguaçu S/A (Cataratas do Iguaçu S/A, 2012). A seguir será apresentado o Passe Comunidade, benefício fornecido aos municípios vizinhos ao PNI.

\section{PASSE COMUNIDADE: BENEFÍCIO PARA OS MUNICÍPIOS BRASILEIROS DO ENTORNO DO PNI}

O texto está ordenado em três etapas, onde inicialmente é abordado o tema turismo e comunidade, posteriormente é apresentado o ingresso Passe Comunidade, os municípios contemplados, as taxas e critérios que devem ser atendidos para obtê-lo, e ao final é apresentada a participação da comunidade na visitação do PNI em 2012.

O turismo e a comunidade são alvos de constantes discussões políticas e acadêmicas, indispensáveis para as políticas de relacionamento estabelecidas e assumidas por entidades que fazem com que a opção por ser ou não socialmente responsável dependa muito mais do interesse das lideranças da entidade, e muito pouco da compreensão de interdependência estratégica, e de comprometimento com o entorno (Baldissera, 2008).

Um exemplo disso é o Passe Comunidade1, Estabelecido pela Portaria n' 504 do Ministério do Meio Ambiente (MMA) (Brasil, 2002), como um ingresso com valor específico para esta demanda concedido através do fornecimento de desconto de $90 \%$ para os residentes das cidades limítrofes da UC.

O ICMBio visa através desta política estabelecer uma relação com a comunidade, de modo que exista interesse estratégico nessa relação, com vistas principalmente para a conservação da unidade através da disseminação do sentimento de pertencimento, que pode ser gerado a partir do momento que estes indivíduos conhecem o PNI.

De acordo com o Plano de Manejo (ICMBio, 1999), e o mapa disponível no anexo $A$, as quatorze cidades contempladas pelo Passe Comunidade são: Foz do Iguaçu, Santa Terezinha de Itaipu, São Miguel do scientific research, environmental education, leisure activities in nature and ecological tourism (Melo, Soares, Siqueira \& Kirschner, 2006).

There are currently six concessionaires providing tourist facilities and service: Macuco Safari, Macuco Ecoaventura, Canion Iguaçu, Hotel das Cataratas, Helisul and Cataratas do Iguaçu S.A.(Cataratas do Iguaçu S/A, 2012). Next, the Community Pass, a benefit offered to the PNI neighboring municipalities, will be presented.

\section{COMMUNITY PASS: BENEFIT FOR BRAZILIAN MUNICIPALITIES BORDERING THE PNI}

The text is organized in three sections: the first addresses the theme Tourism and Community; the second presents the Community Pass, the municipalities it includes, the rates and criteria to assign the benefit; and the last section displays the visits of the community to PNI in 2012.

Tourism and Community are a permanent topic in political and academic discussions, essential for the entities to put forward policies of relationship. The option to be or not socially responsible depends much more on the entities' leaderships interests than on the understanding of strategic interdependence and the commitment towards the environment (Baldissera, 2008).

The Community Pass2 is an example of that. Created by the Ministry of Environment (Ministério do Meio Ambiente - MMA), by ministerial ordinance n. ${ }^{\circ} 504$ in 2002 (Brasil, 2002), as a ticket with a specific price for that target segment, it gave a $90 \%$ discount to the inhabitants of the neighboring cities of the PNI.

ICMBio, through this initiative, aims to establish a relation with the community, so that a strategic interest arises in order to promote the conservation of the unit through a widespread sense of belonging, which can be enhanced by visiting the PNI.

According to the Management Plan (ICMBio, 1999) and the map (Annex A) there are fourteen cities which can benefit from the Pass: Foz do Iguaçu, Santa Terezinha de Itaipu, São Miguel do Iguaçu, Medianeira, Serranópolis do Iguaçu, Matelândia, Ramilândia, Céu Azul, Vera Cruz do Oeste, Santa Tereza do Oeste, Lindoeste, Santa Lúcia, Capitão Leonidas Marques e Capanema. 
Iguaçu, Medianeira, Serranópolis do Iguaçu, Matelândia, Ramilândia, Céu Azul, Vera Cruz do Oeste, Santa Tereza do Oeste, Lindoeste, Santa Lúcia, Capitão Leonidas Marques e Capanema.

A taxa de ingresso aos Parques Nacionais abertos à visitação é regulamentada pelo MMA, e cabe a concessionária administrar a arrecadação e repasse deste valor ao ICMBio, que é responsável pela administração das unidades de conservação e está diretamente subordinado ao MMA (Brasil, 2010).

De acordo com a Portaria n० 504 do MMA (Brasil, 2002)2, os visitantes que compõem a demanda da comunidade podem obter o ingresso com valor de aproximadamente $10 \%$ da taxa de ingresso, mais o valor referente ao custeio do transporte (já com desconto oferecido pela concessionária), e crianças (de dois a onze anos), e os idosos (a partir de 60 anos) pagam apenas o valor da taxa do transporte, ficando isentos do valor referente a taxa de ingresso, conforme detalhado no endereço eletrônico citado abaixo (Cataratas do Iguaçu S/A, 2012).

No entanto para comprovar que compõem esta demanda é necessário que alguns prérequisitos sejam atendidos pelos visitantes: possuir meio de comprovação de residência3, documento de identificação e, com isso efetuar o cadastro junto às bilheterias.

Será necessário que cada adulto apresente um comprovante de residência para efetuar o cadastro, sendo possível estender o benefício aos dependentes menores de 18 anos e cônjuge, cujo vínculo seja comprovado, através de cédula de identidade, certidão de nascimento do filho ou certidão de casamento (Cataratas do Iguaçu S/A, 2012).

Foi observado que em 2011 e 2012, 51\% dos visitantes tiveram origem nacional, e destes apenas 3\% são representados por moradores da comunidade (Cataratas do Iguaçu S/A, 2012), o que pode apontar o desconhecimento do benefício por parte da comunidade, ou ainda indicar a ausência do sentimento de pertencimento por esta população. $O$ que de qualquer forma sugere que seja feito um estudo aprofundado para conhecer efetivamente a causa para que se possa concretizar esta ação citada no Plano de Manejo.

A tabela a seguir apresenta a participação por município em relação ao percentual de visitantes que cada cidade possui. Os dados
The fees for the entrance in the National Parks are regulated by MMA, it is duty of the concessionaire manage, collect and transfer this value to ICMBio, which is responsible for the management of protected areas and directly subordinated to MMA (Brasil, 2010).

According to the ordinance n. $\circ 504$, of the MMA (Brasil, 2002), the visitors that compose the community demand can get a cheaper ticket. It costs approximately $10 \%$ of the entrance fee, plus the amount for transport (discount already offered by the dealership); children (from two to eleven years old) and seniors (above 60 years) pay only the transport fee, being offered the ticket to the PNI (Cataratas do Iguaçu S.A, 2012).3 However, to prove that they are entitled to the reduced fares it is required that these visitors meet some prerequisites; namely, proof of residency4, identification and they must register at the box office.

It will be necessary a proof of residency and a complete registration, being possible to extend the benefit to dependents under age of 18 and to the spouse; the family relationships must be attested through identity card, child birth certificate or marriage certificate (Cataratas do Iguaçu S/A, 2012).

It was observed that in 2011 and 2012, $51 \%$ of visitors were Brazilian, and of these only $3 \%$ are community residents (Cataratas do Iguaçu S/A, 2012), which suggests that the benefit is not well known, or that the community lacks the sense of belonging. In any case, further and deeper research is needed in order to establish the causes for this situation and effectively implement this action cited in the Management Plan.

The following table presents the participation by municipality concerning the percentage of visitors that each city has. The data are from the Brazilian Institute of Geography and Statistics (Instituto Brasileiro de Geografia e Estatística - IBGE) and the PNI, referring to 2012 (TABLE 1- Community Pass: Proportional share of the population from the neighboring cities in 2012. SOURCE: IBGE/ ICMBio/The Authors, 2014).

In proportion, the population who visited the most the PIN came from Foz do Iguaçu $(17.11 \%)$, followed by Santa Teresina de Itapúa $(7.89 \%)$ and in third was Medianeira $(5.97 \%)$. It is noteworthy that these are the closest cities to the main access to the PNI. The main methods used in tourist data collection are presented below. 
são com base no IBGE e no PNI ambos relativos ao ano de 2012 (TABELA 1- Passe Comunidade: Proporção da participação da população dos municípios na visitação do PNI em 2012. FONTE: IBGE/ICMBio/Os Autores, 2014).

Em proporção, as três cidades em que a população mais visitou o PNI foi a de Foz do Iguaçu, onde $17,11 \%$ dos habitantes visitaram a unidade, em seguida está Santa Terezinha de Itaipu, com $7,89 \%$ da sua população representada, e a terceira maior participação é da localidade de Medianeira com 5,97\% de participação na visitação, vale ressaltar que estas cidades estão entre as mais próximas do acesso principal ao PNI. Adiante serão apresentadas as principais metodologias para coleta de dados turísticos.

\section{METODOLOGIAS UTILIZADAS EM TURISMO}

A seguir serão apresentadas as principais metodologias utilizadas em estudos turísticos, observadas em âmbito nacional (Viegas, n.d.), e que podem ser comparadas às metodologias utilizadas em um atrativo turístico.

As cinco principais categorias de metodologias empregadas no turismo, para a obtenção de dados estatísticos identificados foram: Contagem nos portões de entrada, entrevistas no destino, Pesquisas domiciliares, Censo de receitas e Censo de operações de câmbio (Oliveira \& Souza, 2013).

a) Portões de Entrada:

É a metodologia elaborada para a contagem de turistas que entram e deixam o local pelos portões de acesso, ela pode ser realizada por censo4 ou amostragem5 (Bull, 1994), onde geralmente é possível obter informações como, o tipo de transporte utilizado, o período da visita, o país de residência e eventualmente a motivação da viagem (Salgado \&Cravo, 2005)6.

b) Entrevistas no destino:

Para Bull (1994), esta metodologia é geralmente aplicada nos portões de saída ou locais de grande concentração de visitantes, buscando informações sobre o perfil do visitante e características da viagem;

As informações fornecidas levam a estimativas do volume e do valor do turismo para o destino turístico, dos perfis dos visitantes e de suas visitas.

\section{METHODS USED IN TOURISM}

Following, the main methods used in tourism research and observed at a national level (Viegas, n.d.) are presented and can be compared to methods used to study tourist attractions.

The five main categories identified of methods applied in tourism to obtain statistical data are the count at the entrance gates, interviews at the destination, household surveys, income census and exchange operations census (Oliveira \& Souza, 2013).

a) Entrance gates:

It is the method created to count the visitors entering and leaving through the access gate, it can be done via census 5 or sampling6 (Bull, 1994), usually is possible to get information such as, type of transportation used, travel period, residence country and, eventually, travel motivation (Salgado \& Cravo, 2005)7.

b) Interviews at the destination:

According to Bull (1994), this method is usually applied at exit gates or at places with high concentration of visitors. The goal is to obtain information about the visitor's profile and travel characteristics;

\begin{abstract}
The information provided leads to an estimation of the volume and value of tourism to the destination, of the visitor's profile and its visits. Opinions about the destination and the attitudes associated to it are also assessed. In this type of research, is difficult to assure that the sample is representative, even despite efforts to guarantee that [...] (Cooper, Fletcher, Wanhill, Gilbert \& Shepherd, 2007 p. 117).
\end{abstract}

c) Household surveys:

The household surveys are based on a past behavior, encompassing past travels, even if, sometimes, intentions studies are used (Cooper et al., 2007).

d) Income census:

This method searches information about the offer, in addition to the income (Bull, 1994), it is possible to gather information about the occupancy rates (Cooper et al., 2007), the arrival numbers, country of residence and length of stay (Salgado \& Cravo, 2005).

e) Exchange operations:

This technique looks into the exchange operations, both the income and the 
Também se extraem opiniões a respeito do destino turístico e das atitudes a ele associadas. Nesse tipo de trabalho, é difícil assegurar que a amostra dos visitantes seja representativa, ainda que haja esforços para garantir o trabalho [...](Cooper, Fletcher, Wanhill, Gilbert \& Shepherd, 2007 p. 117).

\section{c) Pesquisas Domiciliares:}

Os levantamentos domiciliares se baseiam em "[...] um comportamento passado, abrangendo viagens já feitas, ainda que, às vezes, se trabalhe com estudos de intenções" (Cooper et al., 2007 p. 115).

d) Censo de receitas:

Este método busca informações sobre a oferta, onde, além das receitas (Bull, 1994), é possível reunir informações sobre os índices de ocupação (Cooper et al., 2007), viabilizando a obtenção de dados, como o número de chegadas, país de residência e permanência do turista (Salgado \& Cravo, 2005).

e) Operações de Câmbio:

É o estudo feito a partir das operações de câmbio, tanto do ingresso, quanto do dispêndio de divisas com turismo emissivo, geralmente estes dados são coletados no Banco Central dos países, que possuem o controle destas operações (Bull, 1994).

\section{VARIÁVEIS}

Neste capítulo serão apresentados conceitos e definições básicas sobre as variáveis, como as qualitativas e quantitativas, as dicotômicas e as politômicas, entre outras subdivisões a fim de simplificar a compreensão dos estudos que são aplicados nos atrativos turísticos (Oliveira \& Souza, 2013).

As variáveis podem ser consideradas como uma classificação ou medida utilizada para descrever fenômenos, ou fatos de uma população (Lakatos \& Marconi, 2003), (Meneses \& Mariano, 2010), "Uma variável é uma característica que pode adotar diferentes valores. Por exemplo, o peso a idade, a inteligência, o rendimento acadêmico, etc." (Bisquerra; Sarriera; Martínez, p. 20, 2007).

As variáveis de medição, mais comumente utilizadas, podem ser subdivididas em qualitativas e quantitativas. As qualitativas referem-se a qualidades (Carvalho \& Campos, 2008) que não podem ser quantificadas, podem ser dicotômicas, a exemplo de sexo ou perguntas de verdadeiro e falso, sim ou não, expenditure of currency by inbound tourism; usually these data are collected from Central Banks of each country which have the control of these operations (Bull, 1994).

\section{VARIABLES}

In this chapter, the concepts and basic definitions about variables will be presented. Namely, qualitative and quantitative, dichotomous and polychromous variables, among other subdivisions to simplify the comprehension of the studies applied to tourist attractions (Oliveira \& Souza, 2013).

A variable can be considered as a classification or a measure to describe phenomena or facts about a population (Lakatos \& Marconi, 2003), (Meneses \& Mariano, 2010), "A variable is a characteristic that can adopt different values. For example, weight, age, intelligence, academic performance, etc" (Bisquerra, Sarriera \& Martínez, p. 20, 2007).

The measurement variables more commonly used can be divided in qualitative and quantitative. The former refers to qualities (Carvalho \& Campos, 2008) which cannot be quantified. They can be dichotomous, for example the gender, "true or false", "yes or no" or "fit or unfit" questions. The polyatomic variables present more than two options, for example social class and education level etc (Bisquerra et al., 2007).

The qualitative variables can be categorical (or nominal) or ordinals (Pinheiro, Cunha \& Carvajal, 2009). The possible values for categorical variables are different in each observation, such as race, nationality and working area. The ordinal variables are different categories ordered, in which each observation can be ranked, as social class or level of education (Carvalho \& Campos, 2008).

Regarding a tourist attraction when it is intended to measure the satisfaction of the visitor in relation to the service/product consumed using the categories very satisfied, satisfied, not satisfied, for example, this can be a qualitative ordinal variable, because there is a hierarchy within the answer. While, for example, the question about the kind of transportation used can be considered as a qualitative nominal variable, since there are many alternatives, without a hierarchy.

The quantitative variables can be measured numerically, such as age or weight; these 
apto ou não apto; já as politômicas apresentam mais de duas categorias, como, classe social, nível de estudos, e etc. (Bisquerra et al., 2007).

As variáveis qualitativas podem ser categóricas, (ou nominais) ou ordinais (Pinheiro, Cunha \& Carvajal, 2009). Nas categóricas seus valores possíveis são diferentes em cada observação, como, raça, nacionalidade e área de atividade. Já as ordinais são diferentes categorias ordenadas, em que cada observação pode ser classificada, como classe social e nível de instrução (Carvalho \& Campos, 2008).

Em um atrativo turístico quando se deseja mensurar a satisfação do visitante com relação ao serviço/produto consumido em - muito satisfeito, satisfeito e não satisfeito - por exemplo, esta pode ser uma variável qualitativa ordinal, pois existe hierarquia na resposta. Enquanto que, por exemplo, o questionamento sobre o meio de transporte utilizado, poderá ser considerado como uma variável qualitativa nominal, uma vez que podem existir várias alternativas sem uma classificação hierárquica.

As variáveis quantitativas podem ser medidas numericamente, como, a idade, ou peso, estas variáveis podem ainda ser discretas, ou contínuas. As discretas são as que podem assumir determinados valores, geralmente inteiros, por exemplo, o número de livros. As contínuas podem assumir qualquer valor intermediário, por exemplo, inteligência ou rendimento acadêmico (Bisquerra et al., 2007), (Pinheiro et al, 2009), (Carvalho \& Campos, 2008).

Nos métodos aplicados em atrativos turísticos a variável quantitativa discreta poderia ser exemplificada pelo questionamento sobre o número de visitantes em um determinado período, enquanto que a variável contínua seria entendida como o gasto per capita durante a permanência no local. O próximo texto apresentará as principais variáveis estudadas em turismo.

\section{VARIÁVEIS EM TURISMO}

A seguir são destacados quatro grupos de variáveis, ou variáveis para estudos macro envolventes (Ferreira, 2005), importantes para a observação do fenômeno em âmbito nacional, mas, para os fins deste estudo, será avaliada a aplicabilidade de cada um deles no espaço de um atrativo turístico. variables can also be discrete or continuous. The former assume a certain value, usually whole numbers, for example, the number of books. The continuous can assume any intermediate value, for example intelligence or academic performance (Bisquerra et al., 2007), (Pinheiro et al., 2009), (Carvalho \& Campos, 2008).

In the methods applied to tourist attractions, the quantitative discrete variable can be exemplified with the question about the number of visitors in a specific period, while the continuous variable could be per capita expenditure during the stay at the place. The next part will present the main variables studied in tourism.

\section{VARIABLES IN TOURISM}

Following, four groups of variables or variables for macro-environment studies (Ferreira, 2005) will be highlighted. These are important to the study of the phenomenon at a national scale, but for the purpose of this research, the applicability of each one of them will be evaluated in terms of applicability in a tourist attraction.

The visitors' influx is the first of these groups of variables. It refers to the volume of tourism measured in terms of the number of people in a given destination (Santos \& Fagliari, 2005), allowing to obtain the movement of foreign visitors, their distribution, transportation used and length of stay (Salgado \& Cravo, 2005).

In the case of tourist attractions, the number of visitors can be measured through ticket selling control, among other information, which can be collected depending on criteria defined by the attraction.

Another group of variables is the profile of demand, which looks for bio-social-economic characteristics of visitors in a certain location, the travel features, as well as the motivation of the travel and decision factors (Santos \& Fagliari, 2005).

In the case of tourist attractions, some investment would be required to obtain this kind of variable, because data on the social profile of the visitor take time and need researchers; it would not be possible to collect these information at the access control or while purchasing the ticket, which is usually a quick process.

The analysis of capital flow is one of the groups of variables indispensable at statistical 
O fluxo de turistas é o primeiro destes grupos de variáveis, pois se refere ao dimensionamento do turismo através da mensuração do número de pessoas em um determinado destino (Santos \& Fagliari, 2005), permitindo obter ainda o movimento de visitantes estrangeiros, sua distribuição, transporte utilizado e permanência (Salgado \& Cravo, 2005).

No caso dos atrativos turísticos, o fluxo de visitantes pode ser medido através do fornecimento de ingressos, além de outras informações, que podem ser coletadas, definidas a critério do atrativo.

Outro grupo de variáveis destacado é - perfil da demanda, que busca revelar informações bio-sócio-econômicas dos visitantes de uma localidade, as características da viagem, trazendo informações como, motivação da viagem e fator decisório (Santos \& Fagliari, 2005).

No caso de atrativos turísticos, para se obter esta variável, seria necessário algum investimento, pois levantar o perfil social do visitante demanda tempo, além de pesquisadores, o que impossibilitaria a coleta no momento em que ocorre o controle de acesso, que geralmente é um processo ágil.

A verificação do fluxo de capital é um dos grupos de variáveis imprescindível nas buscas estatísticas dos países, pois trata do montante de recursos financeiros movimentados (Salgado \& Cravo, 2005).

Para um atrativo também seria um dado indispensável, pois conhecer a origem do capital pode orientar campanhas de publicidade no sentido de aumentar a visitação ou o consumo per capita no local, por exemplo.

Como último grupo identificou-se o das dimensões da oferta, que citam as características da oferta de um destino, como, quantidade de leitos, atrativos, e estabelecimentos gastronômicos (Santos \& Fagliari, 2005). Com estas informações é possível realizar o censo dos pernoites, que consiste na verificação da média de permanência, nos meios de hospedagem (Salgado \& Cravo, 2005).

Para os atrativos, deve ser importante conhecer os produtos e serviços que pode oferecer, até mesmo a fim de informar aos visitantes. Em outra perspectiva, o atrativo é parte da oferta turística, tornando-se base para as informações do destino. data collection about countries, because it addresses the amount of financial resources transferred (Salgado \& Cravo, 2005). Regarding an attraction, it would be of great value as well, since knowing the source of the capital could help targeting ad campaigns so that visits and per capita expenditure on site, for example, increase.

The last group of variables identified refers to the dimension of supply, which encompasses destination features such as hotel bed-spaces, tourist attractions and restaurants (Santos \& Fagliari, 2005). This data will enable a census of overnight stays at accommodation establishments (Salgado \& Cravo, 2005).

To the attractions, knowing the products and services they can offer is essential, if only to inform the visitors. From another perspective, the attraction itself is part of a larger tourist offer, upon which is based the destination information.

The study of the aforementioned variables is of great value when considering the competitiveness of the attractions, and their role in the design of strategies to respond to new market challenges. Next, the methodology used to develop this study will be presented.

\section{METHODOLOGY}

Subsequently, the five development stages of the research are displayed: literature review and document analysis, getting the necessary consents, field research, sample selection and data analysis.

At first, a literature review and document analysis was conducted to gather information about applied tourism statistics, methods and observed variables. Thus, identifying methods used in tourism, and its applicability to tourist attractions.

It was found that the methods of statistical data collection at the PNI could be used as research sample, and in the second moment a survey of official documents was conducted on the PNI, such as the Management Plan, ministry ordinances, laws, rules and regulations relating to ticket fees, as well as data on visits using the Community Pass.

The third stage consisted of a field survey, which was conducted after obtaining the permission from ICMBio to carry on the study, from April to May 2013. The sample selected for the research was the method for 
Os estudos das variáveis analisadas podem ser um dos fatores determinantes na competitividade dos atrativos, em vista de que podem contribuir para a construção de estratégias a fim de responder aos novos desafios do mercado. A seguir será apresentada a metodologia empregada para desenvolver este estudo.

\section{METODOLOGIA}

A seguir serão apresentadas as cinco etapas em que o estudo foi desenvolvido, desde a revisão teórica e documental, a autorização necessária, a pesquisa de campo, a seleção da amostra até a análise dos dados.

No primeiro momento foi realizada a pesquisa bibliográfica em livros e artigos científicos que tratavam sobre estatística aplicada ao turismo, metodologias utilizadas e variáveis observadas, com finalidade de identificar as metodologias que são utilizadas em turismo, e a sua aplicabilidade em atrativos turísticos.

Foi constatado que as metodologias para coleta de dados estatísticos do PNI poderiam servir como amostra da pesquisa, e no segundo momento foi realizado um levantamento dos documentos oficiais sobre - PNI, como o Plano de Manejo, portarias, leis, normas e regulamentos relacionados à cobrança de ingressos, além dos dados da visitação do Passe Comunidade.

A terceira etapa consistiu em uma pesquisa de campo, que foi realizada logo após a obtenção da autorização do ICMBio para realizar o estudo, de abril a maio de 2013, onde foi selecionado como amostra para este estudo uma metodologia para cálculo de demanda, a utilizada para fornecer ingressos aos visitantes oriundos das cidades limítrofes ao PNI, o Passe Comunidade.

Para isso também foi obtido o apoio da concessionária Cataratas do Iguaçu S/A, que é responsável pela operacionalização da cobrança de ingressos, fornecendo 0 fluxograma encontrado no anexo $B$, contendo todas as etapas do procedimento analisado neste estudo.

Na quarta e última etapa do estudo é desenvolvida a análise dos dados com base no fluxograma do anexo $B$, e de acordo com as informações obtidas a partir da pesquisa bibliográfica e documental, por fim são comentadas as considerações finais. calculating demand through the tickets for visitors coming from the neighboring cities to PNI, the Community Pass ticket.

For this purpose, the support from the concessionaire of the Cataratas do Iguaçu S/A, was also obtained. That entity is responsible for the ticket sales, providing the flowchart shown in Annex B, containing all stages of the procedure analyzed in this study.

In the fourth stage of the study, the data analysis is performed based on the flowchart in Annex B, and according to the information obtained from literature review and documentary research. At last, the final considerations are discussed.

It should be noted that by the MMA Ordinance No. 135 (Brasil, 2010) visitors from countries of the Southern Common Market (MERCOSUL), for Brazilians and for residents of neighboring towns are awarded entrance discount fees. That leads to different ticket fares, however this fact is not justified in the documents analyzed, but it is noteworthy that the objective of this study does not cover this issue, and so it was not addressed in this research.

After the presentation of the necessary steps to carry out the research, data will be now analyzed. An overview of the existing methods and variables in tourism and their application to a natural tourist attraction will be discussed. Forward, based on the content studied, data will be presented and analyzed.

\section{PRESENTATION AND DATA ANALYSIS}

The Cataratas do Iguaçu S/A is the concessionaire responsible for collecting tickets and it operates in accordance with current legislation, respecting the Management Plan and all ordinances relating to the ticket fees and documents for proof of residency. The control takes place at the box office when the visitor purchases the ticket at the PNI entrance.

The statistical methods for calculation of demand in the community under analysis, displayed in Annex B, consisted of seven moments, or potential questions that will be put to visitors and used during the analysis of the next phases of the study:

1 - Do you have the documentation necessary to complete the registration and get the discount? 
É necessário destacar que a Portaria MMA No 135 (Brasil, 2010) estabelece descontos para visitantes oriundos de países do Mercado Comum do Sul (MERCOSUL), para brasileiros e para moradores das cidades limítrofes, o que ocasiona valores de cobrança distintos, no entanto este fato não é justificado nos documentos analisados, mas vale ressaltar que o objetivo deste estudo não abrange este tema, e por isso não coube abordar o assunto nesta pesquisa.

Apresentadas todas as etapas necessárias para a realização da pesquisa, a seguir serão analisados os dados, discutindo a teoria acerca das metodologias e variáveis existentes no turismo e sua forma de aplicação para um atrativo turístico natural. Adiante serão apresentados e analisados os dados com base no conteúdo estudado.

\section{APRESENTAÇÃO E ANÁLISE DE DADOS}

A Cataratas do Iguaçu S/A é a concessionária responsável pela cobrança dos ingressos, e atua de acordo com a legislação vigente, respeitando o Plano de Manejo e todas as portarias relacionadas ao valor cobrado, e documentos para comprovação de procedência. $O$ controle ocorre nas bilheterias no momento em que o visitante adquire o bilhete de entrada do Parque.

Para a metodologia estatística para cálculo de demanda da comunidade em análise, disponível no anexo $B$, foram identificados sete momentos, ou prováveis questionamentos propostos ao visitante, que serão utilizados durante as análises das próximas fases do estudo:

1 - Possui a documentação necessária para efetuar o cadastro e obter o desconto?

2 - É a primeira visita como residente das cidades Limítrofes ao PNI?

3 - Possui dependente menor ou cônjuge, que seja contemplado pelo desconto sob o cadastro do mesmo documento?

4 - Quantos serão os visitantes cadastrados através da comprovação apresentada?

5 - Qual a categoria dos visitantes cadastrados através da comprovação apresentada?

6 - Chegaram com veículo particular/ Utilizam o estacionamento?

7 - Qual será a forma de Pagamento preferida?
2 - Is this the first visit as a resident from the neighboring cities of the PNI?

3 - Do you have any dependent minor or spouse, who is covered by the discount under the same registration?

4 - How many visitors will be registered under the same registration?

5 - Which is the category of the registered visitors through the documents presented?

6 - Did you come on your own vehicle? Did you use the parking lot?

\section{7 - Which form of payment will be used?}

The results are organized into four stages: the first stage deals with the main categories of methodologies for data collection, the second analyzes the major classifications of the variables, and finally the main variables found in tourism.

\section{ANALYSIS OF THE MAIN CATEGORIES OF METHODS}

Initially, the methodology under analysis will be compared with the five main categories of methods (Oliveira \& Souza, 2013) used in tourism studies, observed nationwide or in a national system of tourism statistics, according to the International Recommendations for Tourism Statistics (RIET) (Viegas, n.d.).

a) Entrance gates: this method is in part compatible with the statistical methodology for calculation of demand under analysis. It counts visitors entering and leaving the site, which can be done by census 8 or sampling 9 and provides information such as the type of transport used, length of stay, country of residence or origin and motivation of the travel (Bull, 1994; Salgado \& Cravo, 2005). However, that is not the case of this method, in which the exactly number of visitors is known and they are exclusively of domestic origin.

b) Interviews at the destination: it is not compatible with the statistical methodology for calculation of demand under analysis, which is applied on the arrival at the attraction. On the contrary, that method is usually applied at exit gates or at places with high concentration of visitors (Bull, 1994), seeking information about the visitor profile and travel characteristics, information that possibly are obtained at the end of the visit:

The information provided leads to an estimation of the volume and value of 
Os resultados estão organizados em quatro etapas: a primeira etapa trata sobre as principais categorias de metodologias para coleta de dados, a segunda analisa as principais classificações das variáveis, e por fim as principais variáveis encontradas em turismo.

\section{ANÁLISE DAS PRINCIPAIS CATEGORIAS DE METODOLOGIAS}

\section{Inicialmente será analisada a} comparabilidade deste método com as cinco principais categorias das metodologias utilizadas (Oliveira \& Souza, 2013) em estudos turísticos, observadas em âmbito nacional ou em um sistema nacional de estatísticas turísticas, de acordo com as Recomendações Internacionais para Estatísticas em Turismo (RIET) (Viegas, n.d.).

a) Contagem nos portões de entrada: esta metodologia pode ser considerada parcialmente compatível com a metodologia estatística para cálculo de demanda em análise, pois contabiliza os visitantes que entram e deixam o local, que pode ser feita por censo7 ou amostragem8, cuja possibilita obter informações, como, o tipo de transporte utilizado, período da visita, país de residência, ou procedência e eventualmente a motivação da viagem (Bull, 1994) (Salgado \& Cravo, 2005)9, o que não é o caso desta metodologia, onde é possível saber exatamente qual é o número de visitantes, que são exclusivamente de origem doméstica.

b) Entrevistas no destino: não é compatível com a metodologia estatística para cálculo de demanda em análise aplicada na chegada do visitante ao atrativo, já que esta é geralmente aplicada nos portões de saída ou locais de grande concentração de visitantes (Bull, 1994), buscando informações sobre o perfil do visitante e características da viagem, informações que possivelmente são obtidas ao final da visita:

As informações fornecidas levam a estimativas do volume e do valor do turismo para o destino turístico, dos perfis dos visitantes e de suas visitas. Também se extraem opiniões a respeito do destino turístico e das atitudes a ele associadas. Nesse tipo de trabalho, é difícil assegurar que a amostra dos visitantes seja representativa, ainda que haja esforços para garantir o trabalho [...].(Cooper et al, 2007 p. 117) tourism to the destination, of the visitor's profile and its visits. Opinions about the destination and the attitudes associated to it are also assessed. In this type of research, is difficult to assure that the sample is representative, even despite efforts to guarantee that [...] (Cooper et al, 2007 p. 117).

c) Household surveys: This method is definitely not compatible with the statistical methodology for calculation of demand under analysis, as it refers to a past behavior, "The questions relate to past behavior, including trips ever made, even if, sometimes, intentions studies are used "(Cooper et al., 2007 p. 115). The Household Surveys are applied after the visitor returned from a trip, aiming to collect information about it. However, this method is questioned in the item reliability of information provided by the fact that tourists are no longer traveling. Furthermore, it can complement the previous methods, providing information on motivation, tourism expenditure and accommodations.

This method refers to past behavior and in order to be employed by tourist attractions, there must be an interest in getting information after the visitors have left the site and have finished their journey. However, if there is a chance to collect information while they are still in the attraction, the feasibility of using this method, depending on the intended purpose, must be considered.

d) Income Census: this method is also not compatible with the statistical methodology for calculation of demand under analysis. Given the fact that this method gives information about the offer, the object of this method, in addition to the income (Bull, 1994), gathers information about the occupancy rates (Cooper et al., 2007), making possible to obtain data such as the number of arrivals, country of residence and staying of the tourists (Salgado \& Cravo, 2005).

e) Exchange operations: also, as in the previous case, this method is based on information of the offer, coming from foreign exchange transactions, entrance and spending of foreign currency by inbound tourism; usually these data are collected from Central Banks of each country, which have the control of these operations (Bull, 1994).

In this method, the attractions are also positioned as part of the tourist offer, providing data for this survey whenever they are performing operations with foreign 
c) Pesquisas domiciliares: Esta metodologia definitivamente não é compatível com a metodologia estatística para cálculo de demanda em análise, pois se refere a um comportamento passado, "As perguntas relacionam-se a um comportamento passado, abrangendo viagens já feitas, ainda que, às vezes, se trabalhe com estudos de intenções" (Cooper et al., 2007 p. 115).

As Pesquisas Domiciliares são aplicadas depois que o visitante retornou de viagem objetivando coletar informações sobre a mesma, no entanto esta metodologia é questionada no quesito confiabilidade nas informações prestadas, pelo fato de o turista não estar mais em viagem, além disso, pode ser complementar para os métodos anteriores, fornecendo informações sobre motivação, despesas turísticas e utilização de alojamentos complementares.

Esta metodologia trata de um comportamento passado e para que esta metodologia fosse empregada por atrativos turísticos, deveria haver interesse em se obter informações após o visitante deixar o local e terminar sua viagem. No entanto se existe a possibilidade de coletar informações enquanto ele ainda está no atrativo, seria necessário avaliar a viabilidade do emprego desta metodologia, dependendo do objetivo pretendido.

d) Censo de receitas: Este método também não é compatível com a metodologia estatística para cálculo de demanda em análise, em virtude de que este estudo trata sobre informações da oferta, o objeto de estudo deste método, que além das receitas (Bull, 1994), reúne informações sobre os índices de ocupação (Cooper et al., 2007), viabilizando a obtenção de dados como o número de chegadas, país de residência e permanência do turista (Salgado \& Cravo, 2005).

e) Censo de operações de câmbio: Igualmente como no caso anterior este método é alimentado por informações da oferta, feito a partir das operações de câmbio, tanto do ingresso, quanto do dispêndio de divisas com turismo emissivo, geralmente estes dados são coletados no Banco Central dos países, que possuem o controle destas operações (Bull, 1994).

Nesta metodologia, os atrativos são igualmente posicionados como parte da oferta turística, fornecendo dados para este levantamento, sempre que estiverem realizando operações com moedas currencies legally. The next part of the text contains the analysis of the main concepts of variables.

\section{ANALYSIS OF THE MAIN VARIABLE CONCEPTS}

Following, the main variable concepts and their applicability to the variables identified in the statistical methodology for calculation of demand under analysis will be presented.

In the case the statistical methodology for calculation of demand under analysis, the variables identified through the analysis of the flowchart in Annex $C$ were the following: Documentation, Source of Origin, First Visit, Dependents, Category, Visitors, Vehicle/ Parking and Form of Payment.

The most commonly used measurement variables can be divided in qualitative and quantitative. Qualitative refer to qualities (Carvalho \& Campos, 2008) that cannot be quantified and can be dichotomous, like gender or questions of "true and false", "yes or no", "fit or unfit". Thus the variables: First Visit, Dependents and Vehicle, which present "yes or no" options, can be considered qualitative dichotomous variables. The variables: Documentation, Source, Category and Form of Payment may have more than two possible answers; therefore, they are defined as qualitative polyatomic variables and must be mutually exclusive and exhaustive (Bisquerra et al., 2007).

The alternatives that are not sorted by importance may be classified as nominal or ordinal (Pinheiro et al., 2009). For example, Documentation (identity card, and proof of residence, e.g. energy or water invoice); Source of Origin (any of the cities covered by the regulation), First Visit (yes or no) and Dependents (spouse or children using the same document to complete the registration).

Depending on the interpretation of the variables identified earlier, it is possible to classify them into nominal or ordinal. Regarding this study, the aspect of income generation is considered; whenever the variable presents this possibility it should have one of its alternatives classified as more important, thus becoming an ordinal variable.

The following variables are considered ordinal: Category (Adult, Child and Senior, being Adult the first alternative, as it is the one that generates more revenue); Vehicle/ 
estrangeiras legalmente. A próxima parte do texto conterá a análise das principais conceituações de variáveis.

\section{ANÁLISE DAS PRINCIPAIS CONCEITUAÇÕES DE VARIÁVEIS}

A seguir serão apresentadas as principais conceituações de variáveis e a sua aplicabilidade para as variáveis identificadas na metodologia estatística para cálculo de demanda em análise.

No caso da metodologia estatística para cálculo de demanda em análise, as variáveis identificadas com base na análise do fluxograma no anexo C foram: Documentação, Procedência, Primeira visita, Dependentes, Categoria, Visitantes, Veículo/Estacionamento e Forma de Pagamento.

As variáveis de medição, mais comumente utilizadas, podem ser subdivididas em qualitativas e quantitativas. As qualitativas referem-se a qualidades (Carvalho \& Campos, 2008) que não podem ser quantificadas, podem ser dicotômicas, a exemplo de sexo ou perguntas de verdadeiro e falso, sim ou não, apto ou não apto.

De acordo com a descrição acima, as variáveis: primeira visita, dependentes e veículo, que apresentam como alternativas de respostas as opções sim ou não podem ser consideradas variáveis qualitativas dicotômicas.

Já as variáveis: documentação, procedência, categoria e forma de pagamento podem apresentar mais de duas alternativas de respostas possíveis, por isso são definidas como qualitativas politômicas, estas variáveis devem ser mutuamente excludentes e exaustivas (Bisquerra et al.,2007).

Podemos destacar como nominais, ou ordinais (Pinheiro et al, 2009) cujas alternativas não estão ordenadas por ordem de importância: Documentação (cédula de identidade, além de comprovante de residência, por exemplo, conta de água ou energia), Procedência (qualquer uma das cidades contempladas pelo regulamento), Primeira Visita (sim ou não) e Dependentes (filhos ou cônjuge, para efeitos de utilização do mesmo documento para efetuar o cadastro).

Logo dependendo da interpretação acerca das variáveis identificadas anteriormente é possível classificá-las em nominal ou ordinal, para este estudo é levado em consideração o aspecto geração de receita, sempre que
Parking (yes or no alternatives, being the first the most important from a revenue perspective); at last, the variable Form of Payment, where all the alternatives, cash or card mean income generation. However, payment in cash is rated with greater importance because it does not entails any other procedures, as it may occur with sales using cards.

The next text will highlight the main concepts of variables applied to tourism.

\section{ANALYSIS OF THE MAIN CONCEPTS OF VARIABLES APPLIED IN TOURISM}

The four groups of variables, or variables used for macro environments studies (Ferreira, 2005), will be outlined below. They are important when observing a phenomenon at a national level, but for the purposes of this study, these variables will be compared with the methodology used in PNI.

a) Influx of tourists refers to the volume of tourism measured in terms of the number of people (Santos \& Fagliari, 2005). It also allows getting information on the movement of foreign visitors, their distribution, transportation used and length of stay (Salgado \& Cravo, 2005). Regarding this study, it can be related to the variables Vehicle/ Parking and Visitors, because through them it is possible to find the number of visitors and the types of transportation used to reach the attraction.

b) Demand profile, seeks to examine bio-social-economic data of visitors from a certain location, the travel features, bringing information on the motivation of the travel and decision factor (Santos \& Fagliari, 2005). This macro-environment does not resemble to any of the variables of the statistical methodology for calculation of demand under analysis. In this case, the variables do not produce enough information to compose the social and economic profile of the visitor who, despite getting the discount on the value of the ticket, does not meet any economic and/ or social prerequisite, as an income limit, for example.

c) Flow of capital is one of the groups of variables indispensable in the countries' statistical data collection, it deals with the amount of funds handled, based on the destination or origin (Salgado \& Cravo, 2005). If observed in the context of the tourist attraction, the variable Form of Payment could 
a variável apresentar esta possibilidade ela deverá ter uma de suas alternativas classificada com maior importância, portanto será ordinal.

As variáveis a seguir são consideradas ordinais: Categoria, com as alternativas, adulto, infantil e idoso, sendo adulto, a primeira alternativa por arrecadar uma receita maior, Veículo/Estacionamento, com a alternativa sim ou não, sendo a primeira alternativa considerada mais importante por caracterizar uso do estacionamento, e geração da receita e por fim a variável forma de pagamento, onde todas as alternativas, dinheiro ou cartão significam geração de receita, no entanto o pagamento em dinheiro é classificado com maior grau de importância devido ao seu ingresso mais rapidamente ao caixa sem passar por outros procedimentos, como pode ocorrer com as vendas através de cartões. O próximo texto destacará as principais conceituações de variáveis aplicadas ao turismo.

\section{ANÁLISE DAS PRINCIPAIS CONCEITUAÇÕES DE VARIÁVEIS APLICADAS AO TURISMO}

Serão destacados a seguir quatro grupos de variáveis, ou variáveis para estudos macro envolventes (Ferreira, 2005), importantes para a observação do fenômeno em âmbito nacional, mas, para os fins deste estudo, serão comparados com a metodologia utilizada no PNI.

a) Fluxo de turistas: se refere ao dimensionamento do turismo através da mensuração do fluxo em número de pessoas (Santos \& Fagliari, 2005), permitindo obter ainda o movimento de visitantes estrangeiros, sua distribuição, transporte utilizado e permanência (Salgado \& Cravo, 2005), se aproximando das variáveis visitantes e veículo/estacionamento, pois através delas é possível encontrar o número de visitantes e um dos tipos de transporte que pode ser utilizado para chegar ao atrativo.

b) Perfil da demanda, que busca revelar informações bio-sócio-econômicas dos visitantes de uma localidade, as características da viagem, trazendo informações como, motivação da viagem e fator decisório (Santos \& Fagliari, 2005). Esta macroenvolvente não se assemelha a nenhuma das variáveis encontradas na metodologia estatística para cálculo de demanda da comunidade em provide this information to the management, revealing information on spending amounts and payment methods; however, the former can also be obtained by calculating the number of visitors organized by categories.

d) The dimension of supply encompasses characteristics of a destination such as hotel bed-spaces, tourist attractions and restaurants (Santos \& Fagliari, 2005). Information that in any way could be compatible with the variables identified in the statistical methodology for calculation of demand under analysis as these address only the demand of an attraction, preventing the collection of data based on the offer of the attraction.

It is possible to verify that only a few macro-environment elements may be compatible with the variables found in the methodology considered, even by the fact that they are observed in a smaller context, the tourist attractions.

Next, the final considerations will be presented.

\section{FINAL CONSIDERATIONS}

In this research, the methodology for collecting statistical data on community demand in a natural attraction was analyzed. It was observed that several of the studied variables and methods are applicable to the tourist attraction, in this case the PNI, which may provide a basis for predicting visits, estimate revenues and some information about the demand profile and thus assisting the management of attractions.

Moreover, it is possible to highlight the strategic importance of engaging the community as part of the target of a natural tourist attraction, thus increasing the sense of belonging of the community and raising the awareness towards the conservation of that protected are. In 2012, the Community Pass represented only $3 \%$ of the visits to the PNI, in other words, $12.70 \%$ of the inhabitants of the fourteen cities visited the conservation unit in this period.

The statistical methodology for calculation of Community Pass demand also stands out as a management tool that enables the management of the visits and upon which a better service can be offered to these target clients. It would be possible as well to crossreference the number of visits by source of origin with the occurrence of irregular activities 
análise, pois elas não originam informações suficientes para compor o perfil social ou econômico do visitante, que apesar de obter o desconto no valor do ingresso não atende a nenhum pré-requisito econômico e/ou social, como um limite de renda, por exemplo.

c) Fluxo de capital é um dos grupos de variáveis imprescindível nas buscas estatísticas dos países, pois trata do montante de recursos financeiros movimentados, tomando como base o destino ou a origem (Salgado \& Cravo, 2005). Se observado no cenário do atrativo, a variável forma de pagamento poderia fornecer esta informação para a gestão do mesmo, trazendo informações sobre valores gastos e forma de pagamento, no entanto a primeira também pode ser obtida através do cálculo do número de visitantes organizado por categorias.

d) As dimensões da oferta citam as características da oferta de um destino, como, quantidade de leitos, atrativos, e estabelecimentos gastronômicos (Santos \& Fagliari, 2005), informações que de forma alguma poderiam ser compatíveis com as variáveis identificadas na metodologia estatística para cálculo de demanda em análise, pois estas tratam apenas da demanda do atrativo, impossibilitando a coleta de informações com base na oferta do atrativo.

É possível verificar que apenas algumas macroenvolventes podem ser compatíveis com as variáveis encontradas na metodologia analisada, até mesmo pelo fato de que são observadas em um cenário menor, o dos atrativos turísticos, a seguir serão apresentadas as considerações finais.

\section{CONSIDERAÇÕES FINAIS}

Neste estudo foi analisada a metodologia para a coleta de dados estatísticos da demanda comunidade em um atrativo natural, e foi possível observar que várias das metodologias e variáveis estudadas são aplicáveis ao atrativo turístico, neste caso o PNI, podendo fornecer bases para previsões de visitação, previsão de receitas e algumas informações sobre o perfil da demanda, o que contribui para a gestão da visitação dos atrativos.

Além disso, é possível destacar a importância estratégica em se envolver a comunidade também como parte do público alvo de um atrativo turístico natural, pensando principalmente em fomentar o sentimento in the bordering areas of PNI. In that way, it could be verified if any changes in the benefit could affect the decrease of these activities.

In the PNI, in addition to the policy of differentiated value of admission fees, there are also environmental education projects. The unit receives students from public schools of different locations for free, to promote the unit and raise the awareness of sustainable practices. The PNI also supports similar initiatives from concessionaires installed at unit.

It is recommended that researchers who are interested in studying similar topics try to understand the legal relationship between public and private entities operating in some Conservation Units in Brazil. This understanding enables researchers to obtain analyses and considerations, which yield consistent observations, which contribute to improve contract management and procedures between the parties.

There is still plenty of room for research on the development of statistical methodologies for tourism. However, it would be of great value to develop a feasibility study for a statistical system specifically targeting the natural and cultural tourist attractions. It would benefit national tourism to the extent that information from these studies would bring structural and management improvements. Advertising campaigns could be better targeted, using the most effective media. In addition, the studies could provide data valuable for managing the country's attractions in a much more competitive and effectively participated way, for those born and living in the neighboring areas of the Conservation Units.

\section{REFERENCES}

Baldissera, R. (2008, Jan/Dez). Relações Públicas, Turismo e Comunidade Local. Anais Unesco/Metodista de Comunicação Regional, São Paulo, SP.

Barretto, M (13. ed.). (2003). Manual de Iniciação ao Estudo do Turismo. Campinas: Papirus.

Bisquerra, R., Sarriera, J. C. \& Martínez, F (2007). Introdução à Estatística. Porto Alegre: Artmed.

Bull, A. La Economía del Sector Turístico (1994). Madrid: Alianza Editorial.

Carvalho, S. \& Campos, W. Estatística Básica Simplificada (2008). Rio de Janeiro: Elsevier.

Cataratas Do Iguaçu S/A (2012). Projeto da Empresa - Documento Referencial. Foz do 
de pertencimento da comunidade que pode passar a ter interesse em contribuir com a conservação de uma área protegida. Em 2012 o Passe Comunidade representou apenas por $3 \%$ da visitação do PNI, ou seja, 12,70\% dos habitantes das quatorze cidades visitaram a UC neste período.

A metodologia estatística para cálculo de demanda do Passe Comunidade destaca-se ainda como uma ferramenta de gestão, que possibilita o gerenciamento da visitação, e embasar melhorias nos procedimentos de atendimento deste público. Ainda seria possível cruzar o número da visitação por localidade com a ocorrência de atividades irregulares nas áreas limítrofes do PNI, a fim de verificar se alguma alteração na política deste benefício poderia influenciar na diminuição destas atividades.

No PNI, além da política de valor de ingresso diferenciado, também existem projetos de educação ambiental, nos quais a UC recebe alunos de rede pública de várias localidades gratuitamente, para divulgar a unidade e promover a sensibilização e conscientização para práticas sustentáveis, além de apoiar iniciativas similares das concessionárias instaladas na UC.

Recomenda-se para pesquisadores que tenham interesse em estudar temas similares, que busquem compreender a relação legal entre os setores público e privado existentes em algumas UC's do país, pois esta compreensão possibilita que os pesquisadores possam obter análises e considerações, que gerem observações consistentes, que contribuam para a melhoria da gestão de contratos e procedimentos entre as partes.

Ainda há espaço para inúmeras investigações acerca do desenvolvimento de metodologias estatísticas para o turismo, no entanto seria de inestimável importância desenvolver um estudo de viabilidade de um sistema de estatísticas para atrativos turísticos naturais e culturais integrado, trazendo benefícios para o turismo nacional, em vista de que com as informações oriundas destes estudos seria possível realizar melhorias estruturais e de gestão pública e privada, direcionando campanhas publicitárias a um segmento de mercado, utilizando veículos de mídia mais eficazes, além de dar condições para que os atrativos do país possam ser geridos de forma mais competitiva e efetivamente participativa da parte daqueles que nascem e vivem na área de abrangência das UC's.
Iguaçu, PR.

Cooper, C., Fletcher, J., Wanhill, S., Gilbert, D., \& Shepherd, R. Turismo, Princípios e Práticas (2007) (3a e.d.). Tradução de Alexandre Salvaterra. Porto Alegre: Bookman.

Decreto de Lei 1035, de 10 de Janeiro de 1939 (1939). Cria o Parque Nacional do Iguaçu. Diário Oficial [da] República Federativa do Brasil, Poder Executivo. Brasília, DF: Poder Executivo.

Ferreira, L. D (2005). Estudo Analítico das Variáveis da Macro Envolvente de um Destino Turístico. Revista de Estudos Politécnico, v.2 n.4, p. 135-147.

ICMBio (1999). Plano de Manejo. Recuperado em 15 maio, 2013 de http://www. cataratasdoiguacu.com.br/manejo/siuc/ planos_de_manejo/pni/html/index.htm

ICMBio (n.d.). Programa de Voluntariado do ICMBio. Recuperado em 30 maio, 2013 de http://pt.scribd.com/doc/51977391/ Programa-de-Voluntariado-PNI

Lakatos, E. M., \& Marconi, M. A (5a e.d.). (2003). Fundamentos de Metodologia Científica. São Paulo: Atlas.

Lei n. 9985, de 8 de Julho de 2000 (2000). Institui o Sistema Nacional de Unidades de Conservação da Natureza. Diário Oficial [da] República Federativa do Brasil. Brasília, DF: Poder Executivo.

Melo, L.A.M.N., Soares, R.V., Siqueira, J.D.P., \& Kirschner, F.F. (2006, Julho). Modelagem de Combustíveis Florestais no Parque Nacional do Iguaçu, PR, Brasil. In.: Revista Floresta, v. 36, 3, p. 415-424.

Meneses, A. \& Mariano, F (2010). Noções de Estatística Para Concursos. Rio de Janeiro: Elsevier.

Oliveira, A.C.R., \& Souza, C.A. (2013). Análise da Metodologia de Coleta de Dados Estatísticos de Visitação - Parque Nacional do Iguaçu. Anais do VII Fórum de Turismo, Foz do Iguaçu PR.

Pinheiro, J. I., Cunha, S. B., \& Carvajal, S (2009). Estatística Básica: A arte de Trabalhar com Dados. Rio de Janeiro: Elsevier.

Portaria 504, de 19 de Dezembro de 2002 (2002). Estabelece novos valores e descontos para o ingresso nos Parques Nacionais. Diário Oficial [da] República Federativa do Brasil. Brasília, DF: Poder Executivo.

Portaria n.o 135, de 30 de Dezembro de 2010 (2010). Atualiza a tabela de preços para a cobrança de ingressos as Unidades de Conservação. Diário Oficial [da] República Federativa do Brasil.Brasília, DF: Poder Executivo. 


\section{REFERÊNCIAS}

Baldissera, R. (2008, Jan/Dez). Relações Públicas, Turismo e Comunidade Local. Anais Unesco/Metodista de Comunicação Regional, São Paulo, SP.

Barretto, M (13. ed.). (2003). Manual de Iniciação ao Estudo do Turismo. Campinas: Papirus.

Bisquerra, R., Sarriera, J. C. \& Martínez, F (2007). Introdução à Estatística. Porto Alegre: Artmed.

Bull, A. La Economía del Sector Turístico (1994). Madrid: Alianza Editorial.

Carvalho, S. \& Campos, W. Estatística Básica Simplificada (2008). Rio de Janeiro: Elsevier.

Cataratas Do Iguaçu S/A (2012). Projeto da Empresa - Documento Referencial. Foz do Iguaçu, PR.

Cooper, C., Fletcher, J., Wanhill, S., Gilbert, D., \& Shepherd, R. Turismo, Princípios e Práticas (2007) (3a e.d.). Tradução de Alexandre Salvaterra. Porto Alegre: Bookman.

Decreto de Lei 1035, de 10 de Janeiro de 1939 (1939). Cria o Parque Nacional do Iguaçu. Diário Oficial [da] República Federativa do Brasil, Poder Executivo. Brasília, DF: Poder Executivo.

Ferreira, L. D (2005). Estudo Analítico das Variáveis da Macro Envolvente de um Destino Turístico. Revista de Estudos Politécnico, v. 2 n.4, p. 135-147.

ICMBio (1999). Plano de Manejo. Recuperado em 15 maio, 2013 de http://www. cataratasdoiguacu.com.br/manejo/siuc/ planos de manejo/pni/html/index.htm

ICMBio (n.d.). Programa de Voluntariado do ICMBio. Recuperado em 30 maio, 2013 de http://pt.scribd.com/doc/51977391/ Programa-de-Voluntariado-PNI

Lakatos, E. M., \& Marconi, M. A (5a e.d.). (2003). Fundamentos de Metodologia Científica. São Paulo: Atlas.

Lei n. ${ }^{\circ}$ 9985, de 8 de Julho de 2000 (2000). Institui o Sistema Nacional de Unidades de Conservação da Natureza. Diário Oficial [da] República Federativa do Brasil. Brasília, DF: Poder Executivo.

Melo, L.A.M.N., Soares, R.V., Siqueira, J.D.P., \& Kirchner, F.F. (2006, Julho). Modelagem de Combustíveis Florestais no Parque Nacional do Iguaçu, PR, Brasil. In.: Revista Floresta, v. 36, 3, p. 415-424.

Meneses, A. \& Mariano, F (2010). Noções de Estatística Para Concursos. Rio de Janeiro: Elsevier.

Oliveira, A.C.R., \& Souza, C.A. Análise da Metodologia de Coleta de Dados
Salgado, M.; Cravo, P (2005). O turismo e a estatística. Algarve. Recuperado em 10 fevereiro, 2013, de http://www.estig. ipbeja.pt/\%7Epmmsc/papers/estatisticappt.pdf

Santos, G. E. O., \& Fagliari, G. S. Práticas e Usos da Estatística no Turismo. RETUR Revista Eletrônica de Turismo, Campo Largo, v. 2, n. 2, p. 7, 2003.

Viegas, M. M. V. A (n.d.). As Estatisticas do Turismo e Uniformização de Conceitos, p. 2-14, [S.I.], [S.I.]. Recuperado em 10 março, 2012 de http://tinyurl.com/ cwep6ow

\section{FOOTNOTES}

1 The acronyms in the article refer to Portuguese words.

2 More information about the Community Pass, go to http://www. cataratasdoiguacu.com.br/portal/ paginas/16-comunidade.aspx

3 Information about the updated prices:

http://cataratasdoiguacu.com.br/portal/ paginas/72-valores-dos-ingressos.aspx

4 Functional Identity / or proof of income; Certificate of registration and vehicle licensing; Voter registration card; Water invoice; Energy invoice; Invoice of fixed or mobile postpaid telephony; Statement of school enrollment; Bank charges documents of banking institutions; Paychecks of private Paychecks of private companies; Extract of the Guarantee Fund for Time of Service (FGTS).

5 Every individual is counted

6 Only a portion of the population is counted

7 The authors present a study based on the methods used by tourism statistical studies of Portugal, related to data collection in the country.

8 All individual are counted

9 Only a share of the e population is counted 
Estatísticos de Visitação - Parque Nacional do Iguaçu. (2013). Anais do VII Fórum de Turismo, Foz do Iguaçu PR.

Pinheiro, J. I., Cunha, S. B., \& Carvajal, S (2009). Estatística Básica: A arte de Trabalhar com Dados. Rio de Janeiro: Elsevier.

Portaria 504, de 19 de Dezembro de 2002 (2002). Estabelece novos valores e descontos para o ingresso nos Parques Nacionais. Diário Oficial [da] República Federativa do Brasil. Brasília, DF: Poder Executivo.

Portaria n. 0 135, de 30 de Dezembro de 2010 (2010). Atualiza a tabela de preços para a cobrança de ingressos as Unidades de Conservação. Diário Oficial [da] República Federativa do Brasil.Brasília, DF: Poder Executivo.

Salgado, M.; Cravo, P (2005). O turismo e a estatística. Algarve. Recuperado em 10 fevereiro, 2013, de http://www.estig. ipbeja.pt/\%7Epmmsc/papers/estatisticappt.pdf

Santos, G. E. O., \& Fagliari, G. S. Práticas e Usos da Estatística no Turismo. RETUR Revista Eletrônica de Turismo, Campo Largo, v. 2, n. 2, p. 7, 2003.

Viegas, M. M. V. A (n.d.). As Estatisticas do Turismo e Uniformização de Conceitos, p. 2-14, [S.I.], [S.I.]. Recuperado em 10 março, 2012 de http://tinyurl.com/ cwep6ow

\section{NOTAS}

1 Informações sobre o Passe Comunidade acessar: http://www.cataratasdoiguacu.com. $\mathrm{br} /$ portal/paginas/16-comunidade.aspx

2 Informações sobre valores dos ingressos atualizados acessar: http://cataratasdoiguacu. com.br/portal/paginas/72-valores-dosingressos.aspx

3 Carteira funcional e/ou comprovante de rendimentos.

Certificado de registro e licenciamento de veículo

Título de eleitor

Conta de água

Conta de energia

Nota fiscal de serviço de telefonia fixa e móvel pós-pago

Declaração de matrícula

Boletos de cobranças de instituições bancárias

Termo de posse de servidores públicos 
Crachás de funcionários da Fundação Parque Tecnológico de Itaipu (FPTI)

Holerites (ou contracheque) de empresas privadas

Extrato de Fundo de Garantia do Tempo de Serviço (FGTS)

4 Todos os indivíduos são contabilizados

5 Somente uma parcela da população é contabilizada

6 Os autores apresentaram um estudo com base nos métodos utilizados por órgãos de Estudos Estatísticos em Turismo de Portugal, respectivos ao sistema de coleta de dados deste país.

7 Todos os indivíduos são contabilizados

8 Somente uma parcela da população é contabilizada

9 Os autores apresentaram um estudo com base nos métodos utilizados por órgãos de Estudos Estatísticos em Turismo de Portugal, respectivos ao sistema de coleta de dados deste país. 


\section{Attachments}

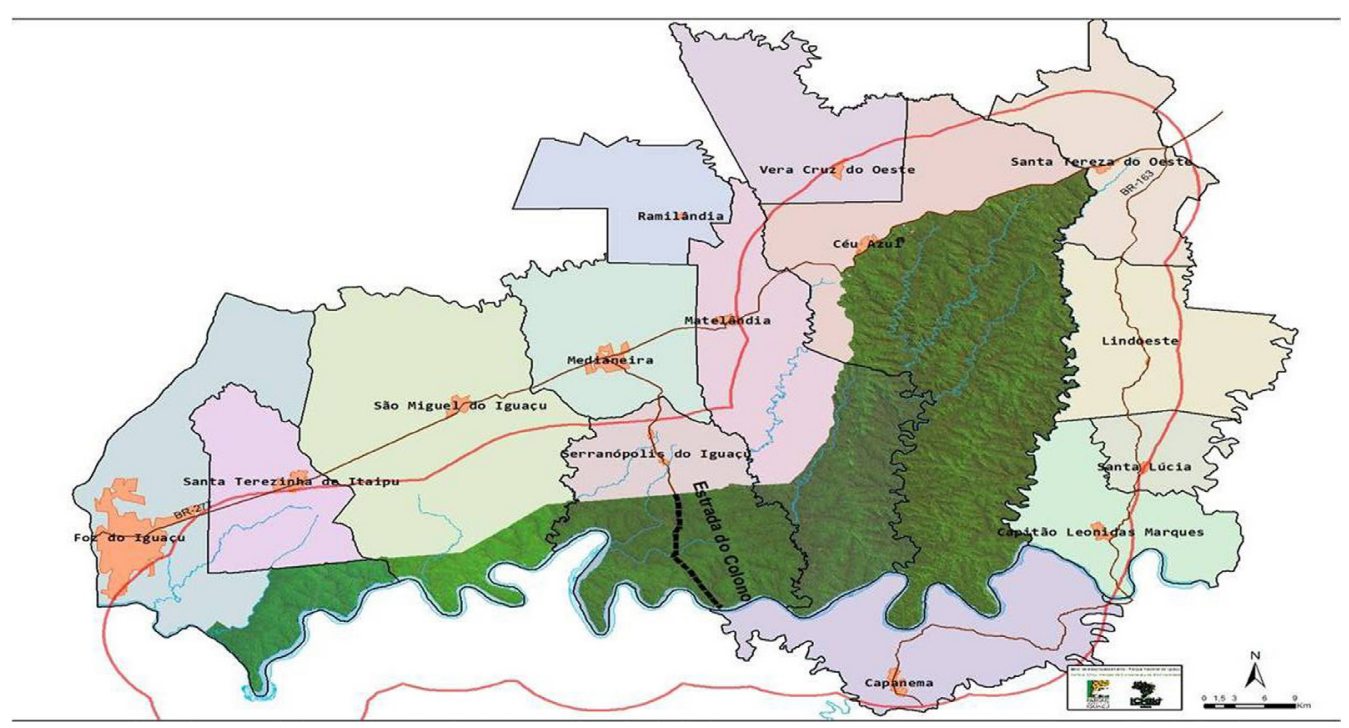

ANEXO A - Mapa da Área do PNI e Cidades Limítrofes

FONTE: Cataratas do Iguaçu S/A (2014)
Appendix A - PNI Area Map and Neighboring Cities SOURCE: Cataratas do Iguaçu S/A (2014)

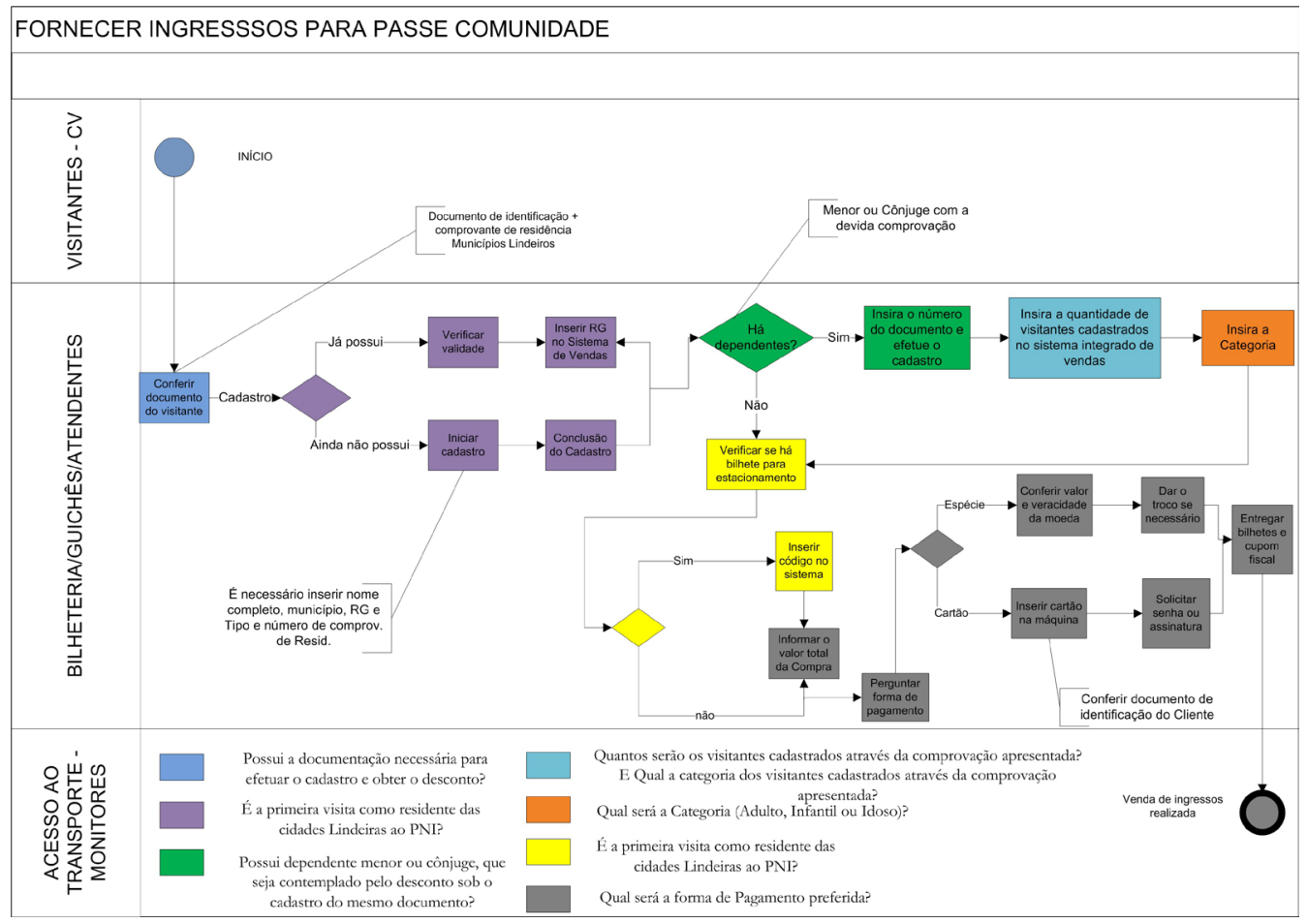

ANEXO B - Fluxograma do Procedimento Realizar Cadastro e Fornecer Ingressos Para Passe Comunidade

FONTE: Cataratas do Iguaçu S/A (2014)
Appendix B - Flowchart of Procedure - Registering and Providing Tickets to Community Pass

SOURCE: Cataratas do Iguaçu S/A (2014) 
TABELA 1- Passe Comunidade: Proporção da participação da população dos municípios na visitação do PNI em 2012. FONTE: IBGE/ICMBio/Os Autores, 2014.

\begin{tabular}{|l|c|c|c|}
\hline MUNICÍPIOS & HABITANTES & $\begin{array}{c}\text { VISITANTES } \\
2012\end{array}$ & $\begin{array}{c}\text { PARTICIPAÇÃO } \\
\text { NA VISITAÇÃO } \\
(\%)\end{array}$ \\
\hline $\begin{array}{l}\text { Capitão Leônidas } \\
\text { Marques }\end{array}$ & 14.970 & 430 & 2,87 \\
\hline Capanema & 18.526 & 447 & 2,41 \\
\hline Céu Azul & 11.032 & 441 & 4,00 \\
\hline Foz do Iguaçu & 256.088 & 43.811 & 17,11 \\
\hline Lindoeste & 5.361 & 89 & 1,66 \\
\hline Matelândia & 16.078 & 785 & 4,88 \\
\hline Medianeira & 41.817 & 2.496 & 5,97 \\
\hline Ramilândia & 4.134 & 99 & 0,02 \\
\hline Santa Lucia & 3.925 & 77 & 1,96 \\
\hline $\begin{array}{l}\text { Santa Terezinha de } \\
\text { Itaipu }\end{array}$ & 20.841 & 1.645 & 7,89 \\
\hline Santa Tereza do Oeste & 10.332 & 319 & 3,09 \\
\hline São Miguel do Iguaçu & 25.769 & 1.388 & 0,05 \\
\hline Serranópolis do Iguaçu & 4.568 & 194 & 4,25 \\
\hline Vera Cruz Do Oeste & 8.973 & 172 & 1,92 \\
\hline TOTAL & 412.511 & 52.393 & 12,70 \\
\hline
\end{tabular}

TABLE 1- Community Pass: Proportional share of the population from the neighboring cities in 2012. SOURCE: IBGE/ICMBio/The Authors, 2014.

\begin{tabular}{|l|c|c|c|}
\hline CITIES & POPULATION & VISITORS 2012 & $\begin{array}{c}\text { VISITATION } \\
\text { SHARE (\%) }\end{array}$ \\
\hline $\begin{array}{l}\text { Capitão Leônidas } \\
\text { Marques }\end{array}$ & 14,970 & 430 & 2.87 \\
\hline Capanema & 18,526 & 447 & 2.41 \\
\hline Céu Azul & 11,032 & 441 & 4.00 \\
\hline Foz do Iguaçu & 256,088 & 43,811 & 17.11 \\
\hline Lindoeste & 5,361 & 89 & 1.66 \\
\hline Matelândia & 16,078 & 785 & 4.88 \\
\hline Medianeira & 41,817 & 2,496 & 5.97 \\
\hline Ramilândia & 4,134 & 99 & 0.02 \\
\hline Santa Lucia & 3,925 & 77 & 1.96 \\
\hline $\begin{array}{l}\text { Santa Terezinha de } \\
\text { Itaipu }\end{array}$ & 20,841 & 1,645 & 7.89 \\
\hline Santa Tereza do Oeste & 10,332 & 319 & 3.09 \\
\hline São Miguel do Iguaçu & 25,769 & 1,388 & 0.05 \\
\hline Serranópolis do Iguaçu & 4,568 & 194 & 4.25 \\
\hline Vera Cruz Do Oeste & 8.973 & 172 & 1.92 \\
\hline TOTAL & 412,511 & 52,393 & 12.70 \\
\hline
\end{tabular}

